\title{
Reuse, Remanufacturing and Environmental Performance: Analysis of Timber Processing Firms in Nakuru County
}

\author{
Osuga Vincent ${ }^{1}$, Muma Benard ${ }^{2}$, Benjamin Nyariki ${ }^{1}$, Mark Ndungu ${ }^{2}$ \\ ${ }^{1}$ Department of Procurement and Logistics, Jomo Kenyatta, Univeristy of Agriculture and Technology, Juja, Kenya \\ ${ }^{2}$ Department of Accounting, Finance and Management Science, Egerton University, Nakuru, Kenya
}

\section{Email address:}

mumabenard@gmail.com (B. Muma),vinnitoh@gmail.com (V. Osuga), bnyariki@gmail.com (B. Nyariki), marikondu@gmail.com (M. Ndungu)

\section{To cite this article:}

Osuga Vincent, Muma Benard, Benjamin Nyariki, Mark Ndungu. Reuse, Remanufacturing and Environmental Performance: Analysis of Timber Processing Firms in Nakuru County. Science Innovation. Vol. 3, No. 3, 2015, pp. 32-38. doi: 10.11648/j.si.20150303.11

\begin{abstract}
This study intended to establish the effect of reuse and remanufacturing on environmental performance of timber processing firms in Nakuru County. This was a case study survey and Comply Company, a company located in the outskirts of Nakuru town was used as a case. Comply Company deals majorly in the processing of timber products like furniture and other wood structures. This study considered all procurement activities of timber processing firms. The study targeted as respondents, employees from production, procurement, finance and accounting marketing departments of Comply Company. The findings of the study revealed that reuse and remanufacturing individually have positive relationship with environmental performance of timber processing firms in Nakuru County. The following recommendations were made from the study; Organizations especially manufacturing and processing should develop environmental management policies that should be well communicated and shared across the organization. These policies should be written down and followed in environmental management. Secondly, management of sustainable procurement strategies and environment should be given a strategic look. The management should align sustainable procurement strategies and environmental management's policies with the overall direction of the organization. Lastly, further studies should be done to identify the management role in adoption of sustainable procurement practices.
\end{abstract}

Keywords: Reuse, Remanufacture, Environmental Performance

\section{Introduction}

In the recent past and even currently, there continues to be growing interest in sustainability across all business functions and all business operations. Such interests build pressure in the operating environment of organizations. To survive such pressure, businesses resort to sustainable business practices. The common sustainable practices adopted by organizations include; reuse, remanufacturing, recycling, waste management and adoption of other green procurement strategies. This study focused on two sustainable procurement practices; reuse and remanufacturing and their relationship with environmental performance.

\subsection{Objectives of the Study}

i. To assess the effect of Reuse on Environmental Performance of timber processing firms in Nakuru County

ii. To determine the effect of Remanufacture on
Environment Performance of timber processing firms in Nakuru County

\subsection{Significance of the Study}

This study aimed to build literature that would stimulate further research on Sustainable Procurement Practices and Environmental Performance. The findings of the study will contribute to adoption of sustainable procurement in timber products manufacturing industry as well as in other manufacturing industries. The recommendations of this study would are useful to procurement organizations and procurement managers in understanding the adoption of sustainable procurement practices and the effects such practices have on environmental performance of organizations adopting them. 


\subsection{Conceptual Framework}

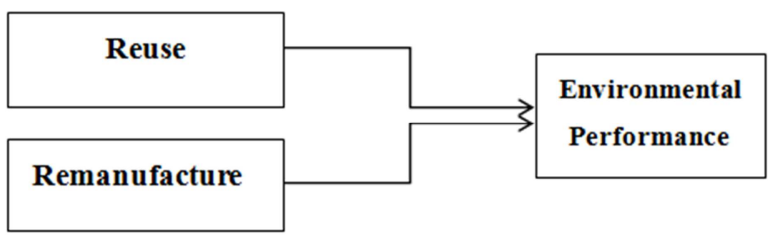

Figure 1.1. Conceptual Framework.

\section{Literature Review}

\subsection{Economic Organization Theory}

Economic organization theory looks at an organization as an entity within and through which individuals interact to achieve individual and collective goals. The main aim of existence of organizations according to this theory is to achieve economic gains. The economic performance of an organization is measured in terms of productivity, profitability and sustainability of its operations (Muma et al., 2014).

The theory of economic organization is grounded on building blocks. The first building block is coordination and motivation. Effective coordination is critical in an organization in deciding on what tasks to be performed, when they are to be performed, by whom they should be performed and in what priority. On the other hand, motivation is important in inspiring the employees to individually and collectively work towards achievement of set goals. The second building block is transactions and contracts. Through transactions, individuals and organizations plan and implement organizational operations. Contracts however provides a means through which agreements between the partners is coordinated. The contracts need not to be written, however, they should be clear be made on continuous basis as the business environment keeps changing. The third building block is bounded rationality. According to Simon (1951), cited by Fudenberg (1990), individuals are limited in their scope to act rationally. This is because of the limitations relating to accessible information and the conception ability of the individuals. The forth building block of the economic theory is the principal-agent framework. In many business activities, the principal agent relationship is adopted. There is need for free flow of information and motivation to ensure the agent knows the principal's requirements and is committed towards achieving them. The last building block is governance structure outlining the rules and regulations and procedures relating to transactions. There must be integration between procurement and other factional areas of the organization. The organization must also have structures that facilitate coordination and cooperation between functional areas (Fundenberg et al., 1990).

Sustainable procurement is one of the strategies that most organizations are currently adopting to achieve economic objectives. This theory brings an understanding on how the organization can align its structure and resources to implement sustainable procurement initiatives. It sets out the need to have coordination between functional areas of the organization, communication and building of organizational structures that facilitates partnership, key ingredients in implementing sustainable procurement.

\subsection{Reuse}

Reuse is one of the most common strategies of outbound logistics. It involves re-injecting the unused products back into the supply chain. Commonly returned products are products that are in good condition that have not been used, the products that have been partially used and are returned for upgrade and products that have completely been used but can be reused in other areas. Hazen et al. (2011) points out that product or material can only be reused if its position in the supply chain is capable of moving in the reverse position. It should not be at the beginning of the supply chain. Reuse maximises value to the organization by making use of materials that would otherwise be regarded as wastes. Reuse also reduces materials extraction, transportation thereby reducing operational costs (Gray and charter, 2014)

\subsection{Remanufacture}

Hazen et al. (2011) defines remanufacturing as the process of repairing, refurbishing or overhauling an item so as to extend its life span or recover the lost value in the item. When a product becomes unusable, the only strategy to restore the usability of the product is through remanufacturing. Remanufacturing is commonly adopted as a sustainable strategy to achieve competitive advantage. If managed strategically, remanufacturing can enhance productivity and improve operational performance of the organization. Remanufacturing includes recycling-integrated manufacturing that aims at reclaiming value from materials that have reached the end of their life span (Sarkis, 2010).

Gray and charter (2014) point out that remanufacturing is mainly driven by the market demand, government regulations and international standards that calls on manufacturers to guarantee customer product quality. It is considered a proactive production method that an organization can use to recover product value and enhance environmental responsiveness. Study conducted by Sustainable Resource Group (2012) reveals that remanufacturing comes with huge financial and environmental opportunity. It can enhance organization's financial and environmental performance. Successful implementation of remanufacturing process require certain conditions; the products should be of high value, the production technology should not change quickly, fashion trends about the product should remain unchanged for a considerable long time, the product should be durable and easy to disassemble and lastly, the product should be leased as a service and not a hard ware.

\subsection{Environmental Performance}

Environmental performance describes a performance of the organization in relation to ecological effects of goods procured by an organization by taking to less environmentally damaging activities (Preuss, 2009). Environmental 
Performance is concerned with Fitness for Purpose, Biodegradability, Design and Disassembly of the products purchased and supplied by the organization. It is the extent to which purchased or supplied products give value for money for the organization and its customers. Indicators of Environmental Performance include: Minimum Use of Virgin and Non-renewable Materials by the organization, Resource, Energy and Water efficiency, Fault and Waste Prevention and Maximum Durability. In addition, environmental performance can be indicated by the level of Reusability and Recyclability of products and Associated Materials, Minimum Packaging, Maximum use of Post-Consumer Materials and Minimum Pollution of products purchased and supplied by the organization (Meehan \& Bryde, 2011).

Study by (Henry \& Journeault, 2007) on Environmental performance indicators: An empirical study of Canadian manufacturing firms, examined the importance of measurement and use of environmental performance indicators within manufacturing firms. The objective of this exploratory study was to identify the associations among firm characteristics and the importance of measurement of EPIs and their use. The results of this study suggest three main conclusions. First, the importance of measurement of EPIs is associated with; firms having a more active environmental strategy, ISO 14001 compliant firms, larger firms, and public firms. Second, the global use of EPIs is also associated with a more active environmental strategy, ISO 14001 compliance, larger firms and public firms. Third, the specific uses of EPIs are associated with different firm characteristics and objectives: monitoring compliance, associated with ISO-compliant firms, motivation of continuous improvement associated with an active environmental strategy and larger firms, decision making associated with an active environmental strategy, and external reporting associated with public firms. This study has analyzed in great depth the EPIs and how they affect overall Environmental Management practices but it has not analyzed the relationship between sustainable procurement and environmental performance of a firm.

Table 2.1. Elements for Improving Environmental Performance (EP) and Compliance.

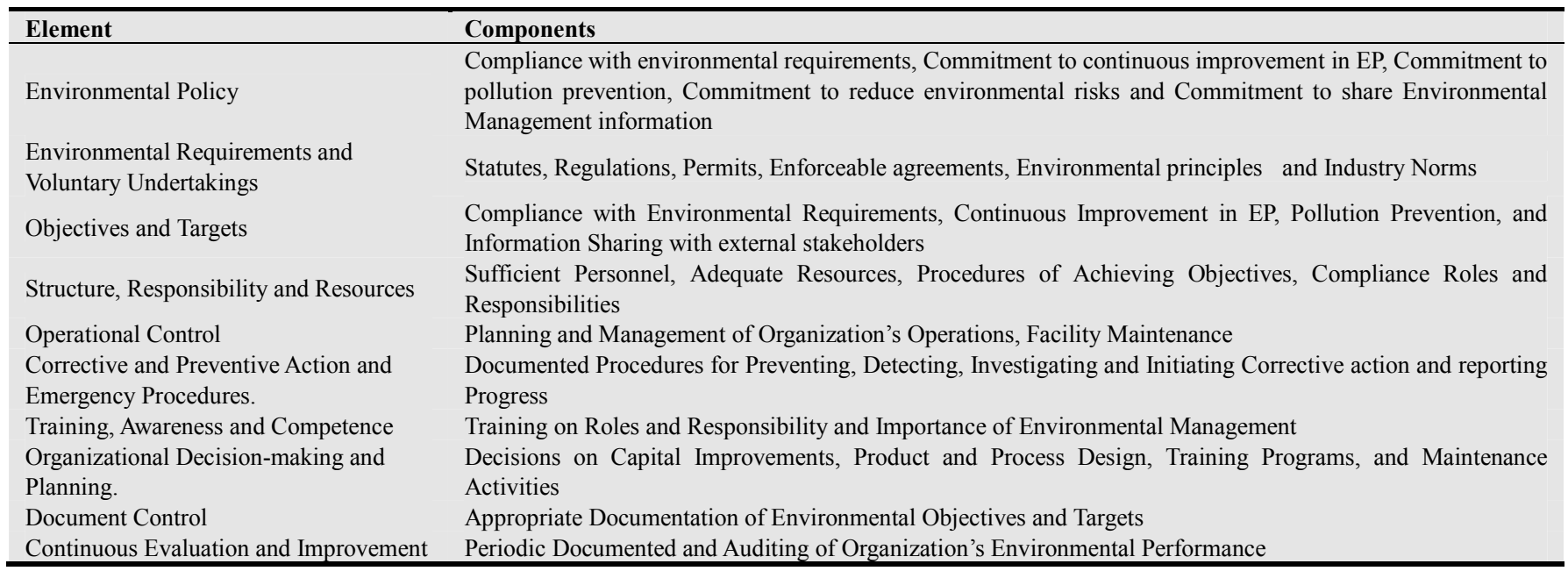

\section{Research Methodology}

The researchers used correlational research design. This design is deemed appropriate as it allows the researcher to draw conclusion on the link between reuse and remanufacture and environmental performance of firms. The study employed a case study census cross-section (conducted at one point in time) survey strategy. Comply Company was chosen because of its accessibility and the fact that the company is practicing sustainable procurement practices. The target population for this study comprised all employees attached to the mentioned departments of Comply Company. The departments were chosen based on their involvement in the procurement process. Since the targeted respondents are only 100, all the respondents were involved in the study. Primary data was collected using structured questionnaires. The filled questionnaires were then collected after one week; this gave respondents enough time to answer the questions promptly. Each item in the questionnaire was developed to address a specific objective or research question. A pilot test was carried at Cabro Timber Processing company procurement department only to determine the feasibility of the data collection instrument. The collected data was keyed into SPSS version 2. Single tailed Spearson's Correlation test was conducted to establish the relationship between reuse, remanufacture and environmental performance.

\section{Findings, Conclusions and Recommendation}

\subsection{Findings on Reuse, Remanufacturing and Environmental Performance}

From table 4.1 , the means $>3.5$ imply that most of the respondents agreed that timber processing firms produce materials that can be reused, reuse products and materials where possible and encourage stakeholders to reuse materials. 
Table 4.1. Findings on Reuse.

\begin{tabular}{|c|c|c|c|c|c|}
\hline Statements & $\mathbf{N}$ & Min & Max & Mean & Std. Deviation \\
\hline Company produces products that can be reused & 61 & 2 & 5 & 4.63 & .720 \\
\hline Company re-uses inputs and materials where possible & 61 & 1 & 5 & 4.08 & .977 \\
\hline Company package materials in re-used packaging materials & 61 & 2 & 5 & 4.35 & .796 \\
\hline Company has in place systems to recover partly used and faulty products & 61 & 1 & 5 & 3.92 & .093 \\
\hline Company encourages distributors and customers to return faulty and used products & 61 & 2 & 5 & 4.33 & .816 \\
\hline Company reuses its packaging materials where possible & 61 & 1 & 5 & 4.02 & .049 \\
\hline
\end{tabular}

Table 4.2. Findings on Remanufacture.

\begin{tabular}{llllll}
\hline Statements & N & Min & Max & Mean & Std. Deviation \\
\hline Your Company repairs products returned by customers & 61 & 4 & 5 & 4.86 & .348 \\
Your company remanufacture faulty products identified before going to the market & 61 & 3 & 5 & 4.57 & .539 \\
Your company refurbishes faulty products identified before going to market & 61 & 3 & 5 & 4.65 & .559 \\
Your company refurbishes faulty products returned by customers & 61 & 3 & 5 & 4.51 & .579 \\
Your company overhauls products where it is not possible to repair or refurbish before & 61 & 3 & 5 & 4.61 & .603 \\
products are taken to market. & 61 & 2 & 5 & 4.49 & .644 \\
Customers are encouraged to bring faulty products back for repair & 61 & 3 & 5 & 4.65 & .559 \\
Company overhauls returned products that are beyond repair or refurbish & 61 & 3 & 5 & 4.51 & .579 \\
Company has in place system to recover faulty products for repair & & & & \\
\hline
\end{tabular}

Table 4.2 reveal that most of the respondents agreed with the statements as evidenced by mean $>3.5$. This implies that timber processing firms repair, remanufacture, refurbishes or overhauls products and materials where possible. The companies also encourage the use of remanufactured products by stakeholders and take the lead in remanufacture use of remanufactured products.

Table 4.3. Findings on Environmental Performance.

\begin{tabular}{|c|c|c|c|c|c|}
\hline Statements & $\mathbf{N}$ & Min & Max & Mean & Std. Deviation \\
\hline Firm emits minimal gases into the environment & 61 & 3 & 5 & 4.65 & .522 \\
\hline Firm deposits minimal solid wastes on land & 61 & 1 & 5 & 4.49 & .834 \\
\hline Wastes by the firm poses minimal environmental risks and hazards & 61 & 1 & 5 & 4.37 & .799 \\
\hline Wastes of the firm are Biodegradable & 61 & 3 & 5 & 4.55 & .702 \\
\hline The firm uses minimal non-renewable inputs and materials & 61 & 1 & 5 & 3.94 & 1.207 \\
\hline The firm uses inputs and materials efficiently & 61 & 1 & 5 & 3.50 & 1.206 \\
\hline The firm uses minimal fuel energy & 61 & 4 & 5 & 4.80 & .401 \\
\hline The firm saves on electric power usage & 61 & 3 & 5 & 4.49 & .612 \\
\hline Products of the firm are Biodegradable & 61 & 1 & 5 & 4.24 & 1.031 \\
\hline Products of the firm are Durable & 61 & 3 & 5 & 4.53 & .703 \\
\hline Products of the organization are Recyclable & 61 & 1 & 5 & 4.37 & .799 \\
\hline Packaging material used by the firm has minimal environmental effects & 61 & 3 & 5 & 4.90 & .100 \\
\hline Firm has environmental protection policies & 61 & 1 & 5 & 4.49 & .834 \\
\hline Management of the firm listens to local community complains on environmental issues & 61 & 2 & 5 & 4.43 & .781 \\
\hline Management of the firm implements environmental protection polices as required & 61 & 2 & 5 & 4.55 & .673 \\
\hline Management has a budget for environmental management efforts & 61 & 2 & 5 & 4.33 & .841 \\
\hline Management compensates people affected by its no eco-friendly policies & 61 & 3 & 5 & 4.53 & .703 \\
\hline Company adheres to international environmental standards & 61 & 1 & 5 & 4.37 & .799 \\
\hline
\end{tabular}

From table 4.3 , it is evident that the timber processing firms enjoy improved environmental performance. This is evidenced by the high means of on the responses. The organizations operate in line with local, governmental and international environmental standards and have in place policies for implementation of such standards. Subsequently, the firms face limited challenges and complaints related to environmental degradation.

\subsection{Correlation Analysis}

Correlation analysis was conducted to establish the relationship between reuse, remanufacture, recycle and waste management and environmental performance. The findings were as shown in table 4.4 
Table 4.4. Correlation Matrix.

\begin{tabular}{lllllll}
\hline & Reuse & Remanufacture & Recycle & Waste Management & Environmental Performance \\
\hline \multirow{4}{*}{ Reuse } & Pearson Correlation & 1 & .011 & .171 & -.212 & $.359^{* * *}$ \\
& Sig. (2-tailed) & & .936 & .189 & .102 & .004 \\
\multirow{5}{*}{ Remanufacture } & N & 61 & 61 & 61 & 61 & 61 \\
& Pearson Correlation & .011 & 1 & .003 & -.042 & .004 \\
& Sig. (2-tailed) & .936 & & .984 & .747 & .973 \\
& N & 61 & 61 & 61 & 61 & 61 \\
\hline
\end{tabular}

Table 4.4 gives the result of correlation analysis on reuse, remanufacture and environmental performance. The Pearson Correlation value of 0.359 indicates that reuse has a positive correlation with environmental performance. The significance value of $0.004<0.005$ indicates that the correlation is statistically significant. It was therefore concluded that there is positive relationship between recycling and environmental performance. Pearson Correlation value of 0.004 indicates a weak positive correlation between remanufacture and environmental performance. The significance value of $0.973>0.005$ indicates that the correlation is not statistically significant. Conclusion was made that there is weak positive relationship between remanufacture and environmental performance of timber processing firms.

\subsection{Summary of Findings}

The findings of this study are summarized in table 4.5.

Table 4.5. Summary of Findings.

\begin{tabular}{|c|c|c|}
\hline No. & Objective & Key Findings \\
\hline \multirow{3}{*}{1.} & $\begin{array}{l}\text { To establish the extent to which timber processing firms in Nakuru County adopts } \\
\text { reuse }\end{array}$ & $\begin{array}{l}\text { Timber processing firms reuse materials, products and wastes } \\
\text { where possible. }\end{array}$ \\
\hline & $\begin{array}{l}\text { To determine the level of environmental performance achieved by timber } \\
\text { processing firms in Nakuru County }\end{array}$ & $\begin{array}{l}\text { Timber processing firms achieve good environmental } \\
\text { performance }\end{array}$ \\
\hline & To assess how the level of reuse affects environmental performance & Reuse has positive effect on environmental performance \\
\hline \multirow[t]{3}{*}{2.} & $\begin{array}{l}\text { To determine the extent to which timber processing firms in Nakuru County } \\
\text { adopts remanufacturing }\end{array}$ & $\begin{array}{l}\text { Timber processing firms repair, remanufacture and refurbish } \\
\text { products where possible }\end{array}$ \\
\hline & $\begin{array}{l}\text { To determine the level of environmental performance achieved by timber } \\
\text { processing firms in Nakuru County }\end{array}$ & $\begin{array}{l}\text { Timber processing firms achieve good environmental } \\
\text { performance }\end{array}$ \\
\hline & $\begin{array}{l}\text { To determine the effect of remanufacture on environmental performance of } \\
\text { timber processing firms in Nakuru County }\end{array}$ & $\begin{array}{l}\text { Remanufacture positively affects environmental performance } \\
\text { of timber processing firms in Nakuru County }\end{array}$ \\
\hline
\end{tabular}

\subsection{Conclusions}

The first conclusion was made that Comply timber processing firm are adopting sustainable procurement strategies; they reuse materials, products and wastes where possible, they repair, refurbish and overhaul faulty and used products as appropriate, they recycle wastes, materials and used materials and products as well as purchase recycle products, they recover and manage wastes properly this is evidenced by the mean score of above 4.0 in most of the statements. Commission for Environmental Cooperation (2000) identified ten indicators of environmental performance which has ten elements. Among them are; environmental policy aimed at enhancing organization's commitment to environmental management, commitment to continuous improvement, elaboration and communication of all environmental requirements and practices to the stakeholders, environmental performance, structure, responsibility and resources required for environmental management, operational control, corrective and preventive action for environmental management, training and competence in environmental management etc.

The second conclusion was made that timber processing firms in Nakuru County are experiencing good environmental performance; they have environmental management policies, employees are trained on environmental management, they experience reduced costs, wastages and complaints on environmental degradation etc. as evidenced by majority of respondents agreeing or strongly agreeing with the statements. These findings are in agreement with findings of Muma et al. (2014) and Green et al (2013) that linked environmental performance with reduced costs in environmental management, reduced waste emission into the environment, reduced complaints on environmental management and existence of environmental policies that are well communicated and followed.

From the conclusions of the study, the study recommends the following; Organizations especially manufacturing and processing should develop environmental management policies that should be well communicated and shared across the organization. These policies should be written down and followed in environmental management. Secondly, Management of sustainable procurement strategies and environment should be given a strategic look. The management should align sustainable procurement strategies and environmental management's policies with the overall 
direction of the organization. Further studies should be done to identify the management role in adoption of sustainable procurement practices.

\section{References}

[1] Amemba, C. S., \& Mburu, N. (2013). Elements of Green Supply Chain Management. European Journal of Business and Management, 2222-2839.

[2] Argandoña, A. (2011). Stakeholder Theory and Value Creation. Working Paper, Chair of Corporate Social Responsibility and Corporate Governance.

[3] Ayadi, S. and Pesqueux, Y. (2007). Stakeholder Theory in Perspective. HAL Id: halshs 00154129.

[4] Australian Government:Department of Sutainability, E. P. (2013). Sustaianble Procurement Guide. Canberra: Commonwealth of Australia.

[5] Bennett, M., \& James, P. (1998). Environment under the Spotlight Current Practice and Future Trends in Environment Related Performance Measurement for Business. London.: Association of Chartered Certified Accountants.

[6] Bowen, F., Cousins, P., Lamming, R., \& Faruk, A. (2001). The role of supply Management capabilities in green supply. Production and Operations Management, 10 (2), 174-8.

[7] Camerinelli, E. (2009). measuring the value of supply chain. Farnhan: Gower publishing limited.

[8] Chege, E. N. (2012). Green supply chain management practice and supply chain performance of private hospital in Nairobi, Kenya. Unpublished MBA Thesis.

[9] Commission for Environmental Cooperation (2000). Improving Environmental Performance and Compliance: 10 Elements of Effective Environmental Management Systems. Guidance Document, Commission for Environmental Cooperation

[10] Chien, M. K., \& Shih, L. H. (2007). An Empirical Study of the Implementation of Green Gupply Ghain Management Practices in the Electrical and Electronic Industry and their Relation to Organizational Performances. Int. J. Environ. Science and Technology., 4, 383-394.

[11] Cooper, D., \& Schindler, P. (2006). Business Research Methods. New York: Mc Graw-Hill Publications.

[12] Department of Housing and Public Works. (2009). Procurement Guidance: Integrating Sustainability into the Procurement Process. The State of Queensland: Department of Housing and Public Works.

[13] Department of sutainability, Environment, Water, Population and Communities (2013). Sustainable Procurement Guide. Australian Government.

[14] Fudenberg, D., Holmstrom, B. and Milgrom, P. (1990) Short-term Contracts and Long-term Agency Relationships. Journal of economic theory, 51:1-31.

[15] Fontaine, C., Haarman, A. and Schmid, S. (2006). The Stakeholder Theory. Academy of Management Executives.

[16] Geroliminis, N. and Daganzo, F. C. (2013). A review of green logistics schemes used in cities around the world. Transport (FIRST): Evaluation Final Report, October 2003.

[17] Giunipero, L. C., \& Eltantawy, R. A. (2004). Securing the upstream supply chain: a risk management approach. International Journal of Physical Distribution \& Logistics Management, 34(9), 698-713.

[18] Global Environmental Management Initiative (1998). Measuring Environmental Performance. A Primer and Survey of Metrics in Use. Global Environmental Management Initiative.

[19] Hassan, M. ( 2013). Sustainable Supply Chain Management Practices and Operational Performance. American Journal of Industrial and Business Management, 42-48.

[20] Hazen, T. B., \& Hanna, J. B. (2011). Diffusion of green supply chain management. The International Journal of Logistics Management, 373-389.

[21] Henry, J.-F.-o., \& Journeault, M. (2007). Environmental performance indicators: An empirical study of Canadian manufacturing firms. Journal of Environmental Management 87 (2008) 165-176, 87(2008), 165-176.

[22] Kombo, D. K., \& Tromp, D. A. (2006). Proposal and Thesis Writing:An Introduction. Nairobi, Nairobi county, Kenya: Paulines Publications Africa.

[23] Kothari, C. (2008). Research Methodology-Methods and Techniques. New Delhi: International (P) Limited Publishers.

[24] Marshall, R. S., Brown, D., 2003. Corporate Environmental Reporting: What's in a Metric? Business Strategy and the Environment 12 (2), 87.

[25] Meehan, J., \& Bryde, D. (2010). Sustainable Procurement Practice. Business Strategy and the Environment, 20 (2011), 94-106.

[26] Mosqaard, M. (2009). Green procurement: A Matter of Organizational Change in Elsam Institute for Samfundsud Vkling of Planlaegning. Ailbord University

[27] Mugenda, O. (2003). Quantitative and Qualitative approaches. Nairobi: Africa Centre for technology studies.

[28] Muma, B. O., \& Nyambega, E. K. (2014). Green Supply Chain. International Journal of Economics, Finance and Management Science, 270-276.

[29] McKenzie, S. (2004). Social Sustainability: Towards Some Definitions. Hawke Research Institute Working Paper Series No 27.

[30] Neely, A., Gregory, M., \& Platts, K. (1995). Performance Measurement System Design: A Literature Review and Research Agenda. International Journal of Operations and Production Management, 15 (4), 80-116.

[31] Nijaki, L. K., \& Worrel, G. (2012). Procurement for sustainable local. International Journal of Public Sector, 25(2), 133-153.

[32] Ninlawan, C. S. ( 2010, March 17-19 ). The Implementation of Green Supply Chain Management Practices in Electronics Industry.

[33] Olga, C. (2012). Sustainable Supply Chain Management: Theoretical Literature Overview. IIIEE Working Paper 2012:1.

[34] Orodho, A., \& Kombo, D. (2002). Research Methods. Nairobi:: Institute of Open Learning. 
[35] Preuss, L. ( 2009). Addressing Sustainable Development Through Public Procurement:. An International Journal, 213-223.

[36] Principles and Practices of Public Procurement (2012). Public Procurement Practice, Sustainable Procurement Practice. CIPS and NIGP.

[37] Queen's Printer and Controller (2006). Environmental Key Performance Indicators. Reporting Guidelines for UK Business. Queen's Printer and Controller.

[38] Roy, J., Nollet, J. and Beaulieu, M. (2006), "Reverse logistics networks and governance structures", Supply Chain Forum. 7 (2) 58-67.

[39] Sarkis, J., Zhu, Q. \& Lai, K., (2010). An Organizational Theoretic Review of Green Supply Chain Management Literature, Working Paper No.201-2011

[40] Saunders, M., Lewis, \& M., Thornhill, A. (2012) Research Methods for Business Students (6 ${ }^{\text {th }}$ Ed). Italy: Pearson education ltd.

[41] Saleemi, N. A. (1997). Purchasing and Supplies Management Simplified (1st Edition ed.). Nairobi: N.A.Saleemi Publishers.

[42] Saleemi, N. A. (1997). Purchasing and Supplies Management Simplified. Nairobi: N.A.Saleemi Publishers.
[43] Supply, C. I. (2011). CIPS Sustainable procurement review. Retrieved January 1, 2015, from CIPS: https://www.cips.org/Documents/Products/Sustainable_Procur ement_Review_\%20n_.

[44] Sustainable Resource Group (2012). Remanufacturing Towards a Resource Efficient Economy. Sustainable Resource Group

[45] The Chartered Institute of Purchasing\& Supply. (2012). Sustainable procurement practice. CIPS and NIGP.

[46] Tang, E., \& Chan, R. (1998). Purchasing Behaviors and Perception of Environmentally Harmful Products. Journal of Marketing Intelligence and Planning.16 (6). 356-362

[47] UNDP. (2008). Enviromental Procurement:Practice Guide. UNDP Practice series (pp. 18-23). New York: UNDP Procurement Support office.

[48] Walker, H., \& Brammer, s. (2007). Sustainable procurement in the United Kingdom public sector. Claverton Down: University of Bath.

[49] Walker, H., \& Philips, W. (2006). sustainable procurement:emerging issues. International public procurement conference proceedings. 